\section{Cultural Factors of Aggression in the Public Space}

\author{
Lilla Młodzik \\ University of Zielona Góra, Poland \\ https://orcid.org/0000-0001-7845-5329
}

Political Preferences 2019, vol. 24: 57-72 journals.us.edu.pl/index.php/PP Submitted: 02/10/2019 Accepted: 22/11/2019

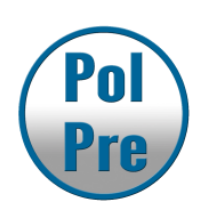

\begin{abstract}
:
The analysis of literature on the subject indicates the occurrence of cultural stereotypes that hinder the adaptation to the conditions of the era of an information civilization. They are of a particular importance in the public sphere. Their main feature (disadvantage) is the stimulation of aggression in social relations, the manifestations of which deform the functioning of liberal democracy. Aggression as a cultural trait comes from the fear of losing identity and from the uncertainty. The dissemination of the patterns of liberal culture and thus the displacement of the restrictive culture are the ways of counteracting the negative phenomena associated with it. The development of this problem is the subject of this text.
\end{abstract}

Keywords: stereotypes, aggression, populism, liberal and restrictive cultures

\title{
Introduction
}

The public space is a particular category, due to a few of its attributes: firstly, it is a domain of life which, in a material, intellectual and cultural dimension, belongs to all (the state, the society, citizens and residents); secondly, it is a public space, an area of social activity and public sentiment; thirdly, is the quintessence of the concept of common good. 'Its action has an impact on the lives and fates of many people, social groups or the entire nation, all taxpayers contribute to its maintenance' (Itrich-Drabarek 2017: 7). The author is particularly interested in the cultural dimension of the public sphere, in which the core are democratic values. It has already been said about the phenomenon of democracy (recognized and categorized in many ways) that there may arise doubts from the mere raising of this issue. To what extent, as Andrzej Antoszewski (2016: 5) claims, may one argue that 'by its virtues, democracy exceeds all possible forms of government'? 


\section{Lilla Młodzik}

The subject of consideration, however, is not democracy as such, but rather issues related to liberal cultural patterns of the public space and their deformation. The essence of democracy, with a multitude of competing definitions (minimalistic, focusing on the way power emerges, realistic, taking into account - apart from elections - additional components, or finally maximalist, describing democracy as an ideal state), with different levels of generality and abstractness (conceptual stretching), is the ability to consult, renounce rape and discrimination against those who are not likeminded, abandon hope of the state's appropriation by one ideological option (Sikorski 2012; Fukuyama 2015). Rejection of these attributes serves no values, it only proffers dictatorship - moral wickedness that some social group wishes to perform. Unlike the latter, democracy allows one to communicate and act without hindrance to one's enemies, possessing a suicidal gene of sorts. As Lance M. King (2017: 188) writes, 'there is no democracy for free.' Affixing the adjective 'liberal' (going beyond the narrow, economic understanding of liberalism) (Lilla 2018), according to David Beetham (1992), one should distinguish the following constitutive elements of liberal democracy: civil liberties and civil rights, separation of power, the rule of law expressed in political practice, the existence of an elected parliament and anti-paternalism expressed in the absence of the 'only truth' in the name of which the rulers create and implement state policy. It seems necessary to mark that this kind of characteristic, referring to the concept of the 'ladder of abstraction' by Giovanni Sartori (1994), places this definition at the lowest level of the abovementioned ladder, due to the large number of attributes. Their absence, or distortion, may be the basis for qualifying a particular case as defective democracy. It may constitute a defect towards perhaps defective forms of authoritarianism (Antoszewski 2016).

Despite this (or maybe exactly for that reason), in the era of information civilization (Bieńkowska \& Sikorski 2016), under the influence of globalisation and the educational revolution, cultural models of liberal democracy, promoting personal responsibility and independence, are much more useful in the public sphere than traditional patterns of obedience and loyalty, shaped in pre-democratic times (among others Fukuyama 2015; Engdahl 2015; Antoszewski 2016; Marciniak 2017; Itrich-Drabarek 2017; Grabowska \& Szawiel 2001). This is hindered by cultural stereotypes that hamper the proper performance of duties by citizens (and such exist!), and thus the proper functioning of the democratic system. Cultivating those stereotypes harms democratic values and, being a source of aggression in the public sphere, 
handicaps any development or modernization of the country in material and spiritual terms. Lance M. King (2017: 181-182) goes even further claiming: 'A social epistemological change has come upon us. Citizens are no longer interested in facts; they do not know them. They find themselves in a narrative based on social networks, or a fairy tale about facts. Fairy tales are pleasant, but the categories of truth and falsehood - however understood - do not play a fundamental role in fairy tales; one you should not confuse moral and truth'. In such an event, according to the author, cultural stereotypes like social prostheses, become even more hazardous. This has nothing to do with the return of authoritarianism in the inter-war spirit, but, perhaps, a completely new dimension of cultural changes in the era of media and the Internet.

The article aims to present aggression as a cultural element that can lead to widespread destruction. Its reduction is an important aspect of the operation of liberal cultures. The research concept is mainly based on a diagnostic survey as a catalogue of features of liberal and restrictive cultures. Techniques (document analysis) and research tools (obtained information and data on the types of cultures discussed) have been selected appropriately for the method used.

\section{Liberal culture vs. restrictive culture}

There are many entities or organisations that exist in the public space. Organisational culture, as a collection of values, norms and patterns of behaviour established in a social environment of a given organisation, is already a generally adopted term. The impact of cultural patterns on the performance of existing entities or any organisation cannot be exaggerated. Currently, among various types we can distinguish restrictive and liberal cultures (Wnuk-Lipiński 2005; Sikorski 2012; Król 2017; Bieńkowska \& Sikorski 2016; Golka 2013; Karsznicki 2014, Stańczyk 2017; Sułkowski 2012; Lilla 2018). Both types are rare in their pure form. However, in indicating the differences between them, it is a confrontation of two attitudes, two philosophies or cognitive perspectives, which manifest themselves more or less clearly, that are in essence a consequence of basic perceptual and ideological choices and, as such, they characterise public sphere cultures.

Restrictive cultures are exclusive and polarising. They are difficult to enter, but also, which is frequently forgotten, they are difficult to leave. Their members are treated very strictly and must rigorously obey and meet certain requirements. If they fail to do so, they are discriminated. Cultures of this type are inherently conservative, because their members see in 


\section{Lilla Młodzik}

historical determinism the justifications of their values and derive a sense of their own reasons. Service to certain values that requires dedication and zeal is at ease with creating enemies, thanks to which, members of restrictive cultures elicit a sense of identity.

It appears, however, that liberal cultures, in contrast to cultures discussed above, are inclusive and tolerant. They can be entered or abandoned just as easily. They are spontaneous, open and voluntary cultures. They may include people with different beliefs who conduct dialogue with each other and negotiate joint ventures. An important quality here is permissivism. The key cultural patterns refer in liberal cultures to the exchange of ideas and thoughts between people and forms of negotiation. Individual identity is here of greater significance than collective identity, which is why they do not seek the enemies. Nevertheless allowing articulation of various outlooks on values and goals may create a sense of confusion and chaos. Generally, they are cultures of longing for something better and more interesting, while not agreeing to live in the spirit of unchanging principles determining permanent and unchanging social roles.

In assessing the two categorised types of cultures, an ethical criterion is necessary. On the grounds of deontological ethics, restrictive culture cannot be defended, because it excludes the use of wicked means to achieve noble goals (Barankiewicz 2013). The view of the need to sacrifice the development of the individual for the benefit of the development of the whole community should be consistently contrasted with the humanistic belief (humanistic management by culture), according to which social development can only be accomplished through the development of individuals. 'The human individual, his development is the first and fundamental value, the basic good on which all other values resulting from the cooperation of individuals are based, i.e. political, economic, national, cultural values, etc.' (Hubert 1997: 4).

Understanding the common good is a complementary matter regarding these cultures in an ethical context. It is connected, regardless of the conditions, with absolute satisfaction of social needs through the public good, which must be provided to citizens due to the implementation of the basic functions of the state. A particular characteristic of public goods is not that they are provided by the state, but that the benefits of using them cannot be limited to merely one person or one household. According to Roman Milewski (2006: 97), pure public goods differ from private goods in two characteristics: First, their use by one person does not

preclude their use by others. Secondly, once they are delivered, it is in practice impossible to exclude anyone from using them. Public goods, therefore, bring great social benefits compared to 
private benefits, which makes them socially desirable.

On the other hand, as claimed by Łukasz Sułkowski (2012), one should not forget about the essence of human nature, about the tendency to rivalry shaped by evolution. The author allegorically refers to the concept of a 'common meadow strategy'. Hardin (1968) describing it as follows: Shepherds grazing sheep in a common meadow face the temptation to increase their own herd, because from the point of view of individual economic rationality the optimal solution is to multiply their own benefit. The expansion of herds is hidden and gradual, because the shepherds do not want to consciously demolish the unwritten social contract or damage the meadow's ecosystem. However, they successively add one sheep to the herds and thus destroy the pasture. 'The tragedy of the common meadow' is a model of a broader social mechanism, examples of which may be observed in the public space (treatment of public goods, such as private, abuse of power and privileges, e.g. means of communication, incorrect asset declarations of officials). Consequently, this leads to over-exploitation and the collapse of the 'common good' (Sułkowski 2012: 10). To limit or mitigate this effect, the author proposes shaping values, norms and patterns cultivating care for the 'common good', building trust through agreements, linked with an effective search system, and above all, sanctioning and punishing fraud. Shaping values, norms and cultural patterns cultivating care for the 'common good' is closely related to the ethics of service (Itrich-Drabarek 2016, 2017; Młodzik 2018). If ethics were to be understood as the science of doing good, it would mean that the foundation of the ethics of service are moral values and norms which determine both ideas and specific behaviours. The ethics of service cannot be considered only as a spiritual or aesthetic sphere, because the law itself does not precisely define certain behaviours that result from everyday duties performed in the public sphere (ItrichDrabarek 2016). Examples of ethical principles relevant from the point of view of current considerations, referring to broadly understood public officials ${ }^{1}$, are reported by Michał Kulesza and Magdalena Niziołek (2010: 76-77, 217-218):

- public work shall be treated as service to people, not as control over people,

- applicable law and moral law shall be obeyed,

\footnotetext{
${ }^{1}$ Today, a public official is, in plain language or in simple terms - everyone employed in the public sphere. This term is derived from Latin - officium and stands for service, duty, obligation. It is now assumed that public service means the situation of persons employed in all constitutionally separate authorities and performing various functions and tasks related to the implementation of the statutory tasks of individual authorities (Kulesza \& Niziołek 2010: 76-77, 217-218). The legal definition of a public official and a person performing a public function is formulated in the Penal Code, Act of June 6, 1997, Penal Code, OJ of 1997, No. 88, item, 553, art. $115 \S 13$, art. $115 \S 19$.
} 


\section{Lilla Młodzik}

- the inherent dignity of all people shall be respected and one shall behave with dignity both in the workplace and outside the workplace,

- others shall not be demoralised with your actions,

- despotism and ruthlessness in contact with people shall be eliminated,

- one shall contribute to the increase of citizens' trust in the state,

- everyone shall be treated fairly, without discriminating against anyone for any reason,

- all people's life shall be protected, every citizen, their rights and freedoms shall be protected,

- culture, tradition, heritage of one's nation and its identity shall be protected,

- in no form and under any circumstances shall a held public office be abused for one's own or other people's particular benefits, one shall be selfless and impartial,

- false information shall not be spread,

- one shall be modest and avoid pride,

- behaviours that could raise the suspicion that a person or group is singularised shall be avoided,

- behaviours that could allow other people to come to the conclusion that one's character cannot be impeccable shall be avoided,

- moderation and caution in public statements shall be maintained, one shall not gossip, be discreet, or demonstrate one's personal attitude towards dealing with matters,

- one shall not advertise their public function, or win customers, applause,

- one shall be calm and tactful, and maintain seriousness necessary for public office,

- while performing public office, one shall not run one's own business enterprise at the same time, or undertake tax initiatives that would interfere with a public office, one shall not engage in any activity for which information obtained in the course of their office could be used,

- in public statements, offensive expressions shall be avoided, one shall not use the threat of criminal or disciplinary prosecution,

- entrusted public office shall be executed to the best of one's knowledge and will, with due honesty, diligence and zeal. 
It is worth emphasizing that with frequent declarations of the abovementioned standards and common reference to service ethics, there is no periodic assessment of ethical standards or ethical screening involving a strategic 'screening' examination of the ethical condition of public officials (Młodzik 2018: 198). Their introduction could improve indicators regarding the implementation of ethical principles by officials. Otherwise, we can talk about the phenomenon of double standards (declaring ethical principles but not following them).

Strong support for liberal culture is the concept of rational egoism by Ayn Rand - an alternative to egoism and altruism. Guided by reason, man is able to achieve his long-term goals, while remaining in harmony with his own social environment. Freedom of action is, in this concept, freedom from physical coercion, enslavement and interference of other people (Rand 2000). Furthermore, as Józef Kozielecki (1998: 67) claims, 'the humanist influence on a human being consists in managing him without manipulation, educating without indoctrination and helping without limiting his independence and freedom of choice'. Furthermore, referring to the concept of an open society, Karl R. Popper (1993: 224) states that 'we must move forward into the unknown, uncertain and dangerous, using reason as a guide in both security and freedom'. According to the author, restrictive subordination to cultural precepts enslaves us and releases us from the obligation to think independently, leading towards a closed, passive society, irrationally accepting rigid customs.

Liberal culture is very often the subject of extensive criticism. It is accused in the grounds of excessive individualism, pressure on individual development and multiplication of achievements, the so-called 'rat race', too clear dominance of flexibility and competition over the needs of security, identity and belonging. But these critics should be asked: which human need is more important from the point of view of human dignity: the need for certainty or rising to the challenges of the surrounding world? According to the author, the latter of the listed needs is definitely of greater significance - the ambition thanks to which man shapes the social environment, and not vice versa, although this process does not occur unscathed.

Czesław Sikorski $(2005,2012)$ notes that all views supporting liberal cultures have emerged in the period of modernism, i.e. when social structures and organisations were dominated by restrictive cultures. On the other hand, currently, in the era of information civilization, which conditions force liberal culture, social discourse in Poland and other postcommunist countries has been overrun by supporters of conservative ideology (Marciniak 2017) 


\section{Lilla Młodzik}

who put a lot of effort to devalue the meaning of pluralism and tolerance and replace the liberal concept of freedom with the 'true freedom', which is in fact a consent to enslavement. In the opinion of Czesław Sikorski (2012: 19): 'The idea of human rights, unchallenged until recently, is also often a subject of mockery and unambiguous allusions, and the system of liberal democracy, which protects the inalienable rights of minorities, is increasingly attacked by those who would be happy to add a national or religious character to democracy or even replace it with a dictatorship'.

An imminent feature of restrictive cultures is aggression directed at other social or political groups that threaten this culture. It can be interesting to discuss this category.

\section{Aggression as an aspect of culture}

The main motive for aggressive actions is to cause fear or a sense of frustration to those at whom they are directed. It is not only about an attack, but can also be defensive in nature and be treated as a response to frustration or fear. Generally, in the opinion of Eliliot Aronson (1997: 303), aggression is 'behaviour aimed at causing harm or unpleasantness'. Therefore, it is not an action strongly motivated by the desire to achieve a goal, but without the intention of harming anyone, as it often seems.

Research shows that aggressive behaviour is favoured by collective rather than individual actions. Group members have a lower sense of personal responsibility than individuals acting in severalty. This is probably due to the fact that people in the collective, strongly identifying group, have a smaller sense of individual identity, which means that they are less concerned about cultural prohibitions regarding aggressive and destructive actions. It is a particularly common phenomenon that the protesting crowd (protesting in some just cause) leaves behind damaged shops and demolished streets. The crowd explains itself in such cases that decent people had been joined by the 'hooligan and pathological element' (according to the author, the latter term has recently been used in public space very often and inadequately). Somehow, however, no one wonders why, in the eyes of decent people, this 'element' had so much freedom of action.

Cultural anthropologists agree that the myth of aggressive war with strangers has always been present in cultures and treated as a factor of internal integration of the group. Not only strangers, but also members of their own community, those differing from the model cultural and personality model: ethnic minorities, infidels and moral unusualness have been blamed for every 
defeat and disaster. They were threatened with banishment at best, and the aggression directed against them was not weaker than that directed against an external enemy.

It has been proven many times and in various ways that aggression should not be treated either as an effective way of psychological recovery, protecting against its further uncontrolled development, or as a means of preventing others from attacks of aggression. As it is well known, the use of violence, as violence is in fact aggression, gives rise to even greater violence. Aggression launches a spiral of aggression. The results of research in this regard are not conclusive. Despite its repulsive nature and very often tragic effects, many people are characterised by a naturalistic approach to aggression, treating it as an innate instinct thanks to which a man is able to fight for their interests, while referring to the law of natural selection, according to which individuals who are worse, weaker adapted and less aggressive, are doomed to lose. The consequence of failure is marginalisation or exclusion, which is in contrast the male's atavistic desire to protect the family from threats, which requires determination, or even brutality (the tendency to aggression is more characteristic of men than women). This view is expressed by, among others Samuel Huntington (2006: 208): 'Hating is human. In order to make up their minds and become motivated, people need enemies: competitors in business, rivals in the pursuit of achievement, opponents in politics. By nature, they do not trust those who are different from them and can do them harm.'

If this path of thought was to be followed, we should still live in caves and dress in untreated skins of killed animals. Although aggression has not disappeared from interpersonal and intergroup relations (riots during the Equality March in Bialystok - 20.07.2019), for example, Mahatma Gandhi has already shown that one can effectively oppose a powerful force without using aggression. Participants of bloodless revolutions in Spain, Portugal or Greece have followed this path. The Polish Solidarity was guided by the same ideal.

With regard to primal groups, the absolute support of aggressive culture was undermined by the results of research by Erich Fromm (2002: 182-187). Based on the analysis of thirty primary cultures, the author distinguished three social systems of which only one - the so-called system C - can be a confirmation of the thesis of instinctive or even innate dimension of aggression. As regards the other two systems: in system A, social relations were not aggressive at all, which did not interfere with the proper functioning of the community, and in system B aggression was controlled, so that its manifestations were by no means destructive. 


\section{Lilla Młodzik}

At present, there is a much greater demand in the public space for collaboration and humanistic values than for cultural models of aggression. I hope that this is not altered by the egoism and frustration of people who want to enforce happiness on humanity, as well as the impact of the worst human traits: aversion to independent thinking and hatred of different patterns of thought, xenophobia and intellectual withdrawal, excluding dialogue and empathy as an element of emotional intelligence.

\section{Aggression in restrictive cultures}

The most common source of aggressive behaviour in the public space are differences between subcultures. Collectivism, understood as following along the lines of the model of patriarchal family relations, based on hierarchy and exaggerated emphasis on the ideal of service (typical for Arab countries and Latin America) is considered to be an element conducive to aggression. The aggression of members of this type of groups is consistent with the Arabic maxim: 'I and my brothers against my cousins. I and my brothers and my cousins against the world'. These are associated with the firm conservative attitudes, most often associated with a strong need for confidence and security. They give a sense of psychological comfort, also resulting from the belief in the validity and effectiveness of such attitudes.

Excluding armed conflicts, aggression in the public space boils down to the polarisation, dehumanisation, appropriation of the public sphere and discrimination. It appears necessary to discuss individual categories.

In the case of polarisation, the overall aim is to identify those guilty of various fears and problems that plague a given group (political, social, organisational). The guilty are isolated, which increases the coherence of the members of the group using polarisation. They feel they are on the good side.

Another focus is dehumanisation. To hate (aggression feeds on hatred,) one must have a good reason to be able to use wicked acts that break the rules of decency without hindrance. Therefore, the opponent should be dehumanised and at the same time deprived of their rights that preclude the application of immoral rules. The dehumanisation process begins at the moment of categorisation, and thus the elimination of individual, personal motives and relationships, 'because we know how they all tend to get'. It is best to give them appropriate epithets: 'dunce', 'pig', 'fool', 'blonde', 'diehard' or 'plague'. Thanks to these one sees even more clearly the 
advantages of their own environment. In the process of dehumanisation, the epithets deprive the opponent of dignity due to honest people, by (ideally) accusing them of a wicked act.

The public space consists of physical and axiological space. The main assumption of aggression with regard to public space is that 'different' members must give up their own identity by imposing physical artefacts on them only in one of the groups. This is followed by an attempt of axiological annexation by imposing one's own values and behavioural norms either through cultural pressure, ridiculing and morally devaluing other cultural patterns or through formal and legal regulations. In that case, legal order is demanded from law enforcement authorities, somewhat threatened by opposing groups. The point is, therefore, to create a situation in which an attempt to challenge a certain norm will be met with open and decisive opposition from a large and influential group that 'anoints' the defender. Consequently, this leads to a change of roles: those who question the norm are accused of aggressive behaviour, while those who defend it are not.

The last of these forms of aggression is discrimination, commonly understood as harassment and exclusion in both psychological and physical aspects. Psychological harassment, today called mobbing (which can take various forms in the internet space - trolling, hate), consists in intimidation, or making threats unjustifiable by the behaviour of the intimidated person; insults, or behaviour that is derogatory to the dignity of the individual; and humiliation or denying the values of the individual. In turn, physical harassment is associated with a clear informal authoritarian hierarchy. Those who are in this hierarchy are supposed to physically harass those who are lower in it. Physical aggression (jerking, pushing, hitting and thus extorting a variety of services) also applies to the use of corporal punishment for all manifestations of disobedience. Exclusion or forcing the abandonment of a group is the ultimate manifestation of discrimination. Aggressive behaviour also applies to liberal cultures.

\section{Aggression in liberal cultures - reduction}

Minimising aggression is actually associated with the use of widely taught ethical principles. These include the following rules: compliance with fair competition rules, acceptance of social diversity, and ideological abstinence (Skarżyńska 1981, 2002; Lipski 1985; WnukLipiński 2005; Sikorski 2012; Trompenaars \& Hampden-Turner 2015). 


\section{Lilla Młodzik}

Today social development depends to a large extent on competition based on the rules followed by everyone. One should not assume that man strives for success, being adventurous and insensitive to the needs of others. This can be done by following the rules. Only then does life and the reality that surrounds us make sense. This sense results from the need for justice, which is lacking in nature. An aggressive individual, who in the neurotic pursuit of power, prestige or wealth, is directed by destructive impulses, e.g. the ability to humiliate, exploit or deceive others, cannot speak openly. That is why great words about duty, responsibility, honour or caring for the common good give succour. It is then that aggression turns into noble sacrifice. Honesty ceases to be a value and is merely an instrument that is to serve the good of the collective. Further, the process is easy and the restraint in breaking the rules is reduced causing moral relativism to progress. Furthermore, the moral universalism guiding compliance with the principles of fair competition simply disappears.

Acceptance of social diversity can be very difficult when threats are seen in 'strangers' or 'others' and variety is treated as a lack of order and an adequate moral guideline. Opponents of tolerance unduly expose the cause of it - not avoiding the hassle of interfering with other people's actions. In this case, however, two attitudes should be distinguished: a lack of reaction to evil and respect for one's views, behaviours that are foreign to us and which we may not like. This is what Voltaire was ready to die for: 'I detest what you write, but I would give my life to make it possible for you to continue to write.' Therefore, tolerance should be treated as an opportunity to enrich oneself with knowledge and experience (tolerance is one of the conditions for development). From the praxeological point of view, it is one of the determinants of achieving the desired goals.

The rules of political correctness are also associated with the principle of acceptance of social diversity. This term is used to describe attitudes promoted in liberal environments. These attitudes are generally directed against all forms of discrimination and inequality. From the stance of political correctness, campaigns are conducted in the sphere of morals and legal regulations. In the moral sphere, this applies primarily to language artefacts from which terms not only considered offensive, but also those that may be associated with discrimination, are eliminated. Currently, there is a broad discussion concerning the issues of 'hate speech' and its causes and effects in public space. In the sphere of legal regulations, political correctness is expressed in the wording of legal acts. An expression of those trends are also statutory guarantees of equal 
representation of women and men or representatives of races or nationalities in various social bodies and authorities.

The principle of ideological abstinence does not aim at weak attachment to a particular ideology, but rather at avoiding too ostentatious demonstration of this internalisation and attachment. This has nothing to do with the lack of noble fidelity to one's principles and it in no way indicates less ideological commitment. Flashy billing does not mobilise cooperation, but on the contrary is ritualistic, which serves to release collective emotions and those, in turn, better mobilize to fight. Ideological abstinence also consists in replacing ideological thinking in social contacts amongst a multicultural environment to pragmatic, from the point of view of achieving the goal, or situational context, and not from the perspective of the principles and assumptions of some ideology. Participants in public discourse should therefore abandon the deeper ideological justifications of their views, limiting themselves to pragmatic conclusions. It is then easier to find an agreement or a compromise solution which does not exclude differences in the assessment of the same phenomenon.

Moreover, minimising aggression involves the implementation of specific rules that apply to all people operating in the public sphere. Among them are those that relate to (Itrich-Drabarek 2016: 38):

- acting in accordance with the law,

- concern for public good,

- political neutrality and impartiality,

- professional loyalty to superiors and colleagues,

- transparency of activities,

- patriotism,

- honour and courage,

- professionalism and efficiency,

- predisposition and desired personality traits.

In the national literature, it should be concluded that the model of civic features proposed by Maria Ossowska (1992: 15-30) is inspiring and still valid. The division of the said author belongs 


\section{Lilla Młodzik}

to the few studies in Poland from a position that is ideologically independent ${ }^{2}$. It covers the following eleven characteristics of a citizen:

1. Possession of perfectionist aspirations.

2. Openness of mind.

3. Constant internal discipline.

4. Tolerance.

5. The subject's activity, understood as an attempt to improve living conditions and striving to realise perfectionist aspirations.

6. Courage.

7. Intellectual honesty.

8. Critical attitude.

9. Responsibility for words spoken in public.

10. Socialisation.

11. An attitude of respect towards an opponent in combat.

Research results on ethical values on which public sphere entities are based are as follows: Not only society expects the individual to act according to the ethical standards mentioned above, but the entities themselves also increasingly understand the need to create and comply with ethical standards. "Sometimes it is also naive thinking, such as "everyone is fundamentally good", sometimes cynical - we could benefit from such a "smokescreen", but more often it is rational thinking, based on the belief that compliance with ethical principles and norms builds a good brand of people, institutions and influences the economic and social development of the state' (Itrich-Drabarek 2017: 12). Such conclusions are optimistic.

\section{Summary}

A review of the literature indicates the existence of cultural stereotypes that are an impediment to adapting to the conditions of the era of information civilization. They are of particular importance in the public space, where they are perceived as particularly sensitive. The main characteristic (disadvantage) of cultural stereotypes is the stimulation of aggression in social relations, the manifestations of which deform the functioning of democracy. Aggression as

\footnotetext{
${ }^{2}$ In that respect, it is recalled that in the period of snowballing Marxist propaganda between 1952 and 1956 , M. Ossowska together with her husband was removed from scientific and didactic work, among others for negating the role of political criteria in science and strictly distinguishing between science and ideology.
} 
a characteristic of culture derives from the fear of losing identity and uncertainty. Counteracting the negative phenomena associated with this involves the dissemination of liberal culture patterns and thus superseding the restrictive culture. These patterns are the foundation for the functioning of various entities in the public space of a democratic state. The development of this problem is the subject of this text. The presented solutions and problems require further empirical research of specific entities in the public sphere, which the author will undertake in the near future.

\section{References:}

Antoszewski, A. (2016). Wspótczesne teorie demokracji. Warszawa: Wydawnictwo Sejmowe.

Aronson, E. (1997). Człowiek - istota społeczna. Warszawa: PWN.

Barankiewicz, T. (2013). W poszukiwaniu modelu standardów etycznych administracji publicznej. Lublin: Wydawnictwo Katolickiego Uniwersytetu Lubelskiego.

Beetham, D. (1992). Liberal Democracy and the Limits of Democratization. Political Studies, 40(1), 40-53.

Bieńkowska, J., \& Sikorski, C. (2016). Ewolucja zarządzania. Dyktat struktury, strategii i kultury. Łódź: Wyd. Uniwersytetu Łódzkiego.

Cialdini, R. B. (2011). Zasady wywierania wptywu na ludzi. Gliwice: Helion.

Engdahl, F. W. (2015). Absolutna dominacja. Totalitarna demokracja w nowym porządku świata. Wrocław: Wektory.

Fromm, E. (2002). Autonomia ludzkiej destrukcyjności. Poznań: Rebis.

Fukuyama, F. (2015). Ład polityczny i polityczny regres. Od rewolucji przemysłowej do globalizacji demokracji. Poznań: Dom Wydawniczy Rebis.

Golka, M. (2013), Socjologia kultury. Warszawa: Scholar.

Grabowska, M., \& Szawiel, T. (2001). Budowanie demokracji. Podziały społeczne, partie polityczne i społeczeństwo obywatelskie w postkomunistycznej Polsce. Warszawa: PWN.

Hardin, G. (1968). The Tragedy of the Commons. Science, 162, 1243-48.

Hubert, J. (1997), Synergetyka i społeczeństwo: model relacji $i$ struktur społecznych oparty na uniwersalnych prawach opisujacych systemy złożone. Kraków: Wydawnictwo Oddziału Polskiej Akademii Nauk.

Huntington, S. (2006). Zderzenie cywilizacji i nowy kształt ładu światowego. Warszawa: Muza.

Itrich-Drabarek, J. (2016). Etyka zawodowa funkcjonariuszy stużb państwowych. Warszawa: Difin.

Itrich-Drabarek, J. (2017). Wstęp. W: J. Itrich-Drabarek (ed.), Etyka sfery publicznej (pp. 7-12). Warszawa: Dom Wydawniczy Elipsa.

Karsznicki, K. (2014). Główne kultury prawne na świecie, Studia Iuridica Toruniensia, 15, 75-89.

Krahe, B. (2005). Agresja. Gdańsk: Gdańskie Wydawnictwo Psychologiczne.

Kozielecki, J. (1998). Koncepcje psychologiczne człowieka. Warszawa: Żak.

Król, M. (2017). Jaka demokracja? Warszawa: Agora.

Kulesza, M., \& Niziołek, M. (2010). Etyka stużby publicznej. Warszawa: Wolters Kluwers.

Kuryłowicz, M. (2001). Słownik terminów i sentencji prawniczych, łacińskich oraz pochodzenia łacińskiego. Warszawa: Wolters Kluwer. 


\section{Lilla Młodzik}

Lilla, M. (2018). Koniec liberalizmu jaki znamy. Warszawa: Fundacja Kultura Liberalna.

Lipski, J. (1985). Dwie ojczyzny i inne szkice. Warszawa: Myśl.

Marciniak, E. M. (2017). O etyce w polityce i etyce polityków. W: J. Itrich-Drabarek (ed.), Etyka sfery publicznej (pp. 95-104). Warszawa: Dom Wydawniczy Elipsa.

Młodzik, L (2018). Kultura współdziałania stużby ochrony bezpieczeństwa publicznego na przykładzie funkcjonariuszy nadodrzańskiego Oddziatu Straży Granicznej. Zielona Góra: UZ.

Ossowska, M. (1992). Wzór demokraty: cnoty i wartości. Warszawa: PWN.

Pieprzny, S. (2007). Ochrona bezpieczeństwa i porządku publicznego w prawie administracyjnym. Rzeszów: Wyd. Uniwersytetu Rzeszowskiego.

Pietrzak, H., \& Gawroński, J. (2012). Psychologia polityki. Rzeszów: Wyd. Uniwersytetu Rzeszowskiego.

Podemski, K. (2019). Potencjalne poparcie spoleczne dla organizacji i ruchów skrajnych w Polsce. Ekspertyza 'policy papers' dla Stowarzyszenia Otwarta Rzeczpospolita.

Popper, K. R. (1993). Spoleczeństwo otwarte i jego wrogowie. t. I. Warszawa: PWN.

PWN (2006). Stownik języka polskiego PWN. Warszawa: Państwowe Wydawnictwo Naukowe.

Rand, A. (2000). Cnota egoizmu. Nowa koncepcja egoizmu. Poznań: Zysk i Spólka.

Sartori, G. (1994). Teoria demokracji. Warszawa: PWN.

Sikorski, Cz. (2005). Język konfliktu. Kultura komunikacji społecznej w organizacji. Warszawa: C.H. Beck.

Sikorski, Cz. (2012). Stereotypy samobójcze. Kulturowe czynniki agresji w życiu społecznym $i$ w organizacji. Warszawa: Difin.

Skarżyńska, K. (1981). Postrzeganie ludzi. Warszawa: PWN.

Skarżyńska, K. (2002). Podstawy psychologii politycznej. Poznań: Zysk i Spółka.

Stańczyk, I. (2017). Zarządzanie kompetencjami w sektorze publicznym. Kraków: Wydawnictwo Uniwersytetu Jagiellońskiego.

Sułkowski, Ł. (2012). Epistemologia i metodologia zarzadzania. Warszawa: PWE.

Trompenaars, F., \& Hampden-Turner, Ch. (2005). Zarzadzanie personelem $w$ organizacjach zróżnicowanych kulturowo. Kraków: Oficyna Ekonomiczna.

Wnuk-Lipiński, E. (2005). Socjologia życia publicznego. Warszawa: Scholar. 